\title{
Rosemary (Rosmarinus officinalis) - a study of the composition, antioxidant and antimicrobial activities of extracts obtained with supercritical carbon dioxide
}

\author{
Alecrim (Rosmarinus officinalis) - estudo da composição, atividade antioxidante e \\ antimicrobiana dos extratos obtidos com dióxido de carbono supercrítico
}

\author{
Aziza Kamal GENENA ${ }^{1}$, Haiko HENSE ${ }^{1 \star}$, Artur SMÂNIA JUNIOR ${ }^{2}$, Simone Machado de SOUZA ${ }^{2}$
}

\begin{abstract}
Rosemary leaf extracts were obtained by supercritical fluid extraction (SFE) and Soxhlet extraction. Their chemical compositions were evaluated by GC-MS. The extracts were analyzed for compounds reported in the literature as showing antimicrobial and antioxidant activities. The rosemary extracts were tested with regard to antioxidant (DPPH radical scavenging and total phenolic content - Folin-Denis reagent), antibacterial (Gram-positive bacteria - Staphylococcus aureus ATCC 25923 and Bacillus cereus ATCC 11778 - and Gram-negative bacteria - Escherichia coli ATCC 25922 and Pseudomonas aeruginosa ATCC 27853) and antifungal (Candida albicans) activities. Antioxidant, antibacterial and antifungal activities of the SFE extracts were confirmed.

Keywords: rosemary; SFE; antioxidant activity; antimicrobial activity.
\end{abstract}

\section{Resumo}

Extratos das partes aéreas de alecrim foram obtidos utilizando fluidos supercríticos (FSC) e extrações Sohxlet. Sua composição foi analisada com GC-MS. Os extratos foram analisados com base nos compostos repostados na literatura como tendo atividade antimicrobiana e antioxidante. Os extratos de alecrim foram testados quanto à atividade antioxidante (radicais DPPH e conteúdo total de fenólicos - reagente Folin-Denis), antibacteriana (bactérias Gram-positivas: Staphylococcus aureus ATCC 25923 e Bacillus cereus ATCC 11778, e bactérias Gram-negativas: Escherichia coli ATCC 25922 e Pseudomonas aeruginosa ATCC 27853) e antifúngica (Candida albicans). As atividades antioxidantes, antibacterianas e antifúngicas dos extratos de FSC foram confirmadas.

Palavras-chave: alecrim; atividade antimicrobiana; atividade antioxidante; FSC.

\section{Introduction}

There is an increasing interest in phytochemicals as new sources of natural antioxidant and antimicrobial agents. The use of synthetic antioxidants in the food industry is severely restricted as to both application and level (TAWAHA et al., 2007; PENG et al., 2005). Currently, there is a strong debate about the safety aspects of chemical preservatives, since they are considered responsible for many carcinogenic and teratogenic attributes, as well as residual toxicity (MOREIRA et al., 2005).

Plant-derived polyphenols receive considerable attention because of their potential antioxidant and antimicrobial properties (MOREIRA et al., 2005; PROESTOS; SERELI; KOMAITIS, 2006). Phenolic compounds exhibit a considerable free-radical scavenging (antioxidant) activity, which is determined by their reactivity as hydrogen- or electron- donating agents, the stability of the resulting antioxidant-derived radical, their reactivity with other antioxidants and, finally, their metal chelating properties (RICE-EVANS; MILLER; PAGANGA, 1997).
Rosemary (Rosmarinus officinalis L.) is a spice and medicinal herb widely used around the world. Of the natural antioxidants, rosemary has been widely accepted as one of the spices with the highest antioxidant activity (PENG et al., 2005). Rosemary essential oil is also used as an antibacterial, antifungal (OLUWATUYI; KAATZ; GIBBONS, 2004; FERNÁNDEZ-LÓPEZ et al., 2005; KABOUCHE et al., 2005; REZZOUG; BOUTEKEDJIRET; ALLAF, 2005) and anticancer agent (LEAL et al., 2003). Ouattara et al. (1997) investigated the antibacterial activity of selected essential oils against some food spoilage organisms. They concluded that the essential oils of cinnamon, clove and rosemary were the most active. Similar results were obtained by Valero and Salmeron (2003) for the antibacterial activity of rosemary essential oil against Bacillus cereus strains grown in carrot broth.

Many compounds have been isolated from rosemary, including flavones, diterpenes, steroids, and triterpenes. Of these,

Recebido para publicação em 25/5/2007

Aceito para publicação em 2/11/2007 (002553)

${ }^{1}$ Laboratório de Termodinâmica e Extração Supercrítica - LATESC, Departamento de Engenharia Química e Engenharia de Alimentos - EQA, Centro Tecnológico - CTC,

Universidade Federal de Santa Catarina - UFSC, CP 476, CEP 88040-900, Florianópolis - SC, Brasil, E-mail: h_hense@enq.ufsc.br

${ }^{2}$ Departamento de Microbiologia e Parasitologia - MIP, Centro de Ciências Biológicas - CCB, Universidade Federal de Santa Catarina - UFSC,

Campus Universitário da Trindade, CP 476, CEP 88040- 900, Florianópolis - SC, Brasil

${ }^{*}$ A quem a correspondência deve ser enviada 
the antioxidant activity of rosemary extracts has been primarily related to two phenolic diterpenes: carnosic acid and carnosol (FRANKEL et al., 1996). The main compounds responsible for the antimicrobial activity are $\alpha$-pinene, bornyl acetate, camphor and 1,8-cineole (DAFERERA; ZIOGAS; POLISSIOU, 2000; 2003; PINTORE et al., 2002).

Supercritical fluid extraction (SFE) is an environmentally benign and efficient extraction technique for solid materials and has been extensively studied for the separation of active compounds from herbs. The interest in SFE has increased in recent years because of legal limits regarding solvent residues (VÁGI et al., 2005), mainly in food industries. Another problem with conventional methods is the high temperatures used, which can cause chemical modifications in the oil components and often a loss of the most volatile molecules.

The objective of this study was to determine the composition and the antioxidant and antimicrobial activities of rosemary leaf extracts obtained with supercritical fluid extraction using carbon dioxide as solvent.

\section{Materials and methods}

\subsection{Raw material characterization and preparation}

Dried rosemary leaves, obtained from the Central de Plantas Medicinais e Aromáticas do Paraná (Curitiba, PR, Brazil), were ground in a domestic mixer (Walita, São Paulo, Brazil) for 10 seconds. The particle size distribution was determined with a vibratory sieve shaker (Bertel Indústria Metalúrgica Ltda., Caieiras, SP, Brazil) using sieves of the Standard Tyler series meshes $-16+80$. Particles of mesh -20 and +32 were used. The ground particles were stored under vacuum and maintained in a domestic freezer (Brastemp, São Paulo, Brazil) below $-10^{\circ} \mathrm{C}$. A Scanning Electron Microscope (Philips, Model XL30) was used to obtain the particle diameter, while a gas pycnometer (Ultrapycnometer 1000, Quantachrome), with helium displacement, was used to evaluate the solid phase density. Moisture was determined through losses of water and volatile substances in a drying oven at $105^{\circ} \mathrm{C}$ (AOAC, 1990).

\subsection{Extraction procedures}

The SFE laboratory unit was designed and built at the Technische Universität Hamburg-Harburg (Germany) and is presented in Figure 1. The unit is composed mainly of a $\mathrm{CO}_{2}$ cylinder, one compressor, an extractor (volume up to $100 \mathrm{~mL}$ ) and three thermostatic baths (one for cooling and two for heating). More details on the laboratory unit are presented by Zetzl, Brunner and Meireles (2003). The pump produced a continuous compressed $\mathrm{CO}_{2}$ flow. The system pressure was controlled by a spring loaded back pressure regulator. After the back pressure regulator, the compressed $\mathrm{CO}_{2}$ passed through the inlet valve into the extractor. The solvent flow was adjusted by a highly sensitive micro-needle valve and metered with a rotameter. The extraction conditions were $0.2 \mathrm{~kg} \mathrm{CO}_{2} \mathrm{~h}^{-1}$, extraction time of 4 hours, 10, 20 and $30 \mathrm{MPa}$ and 303.15, 313.15 and $323.15 \mathrm{~K}$, indicating solvent densities from 385.3 to $948.6 \mathrm{~kg} \mathrm{~m}^{-3}$.

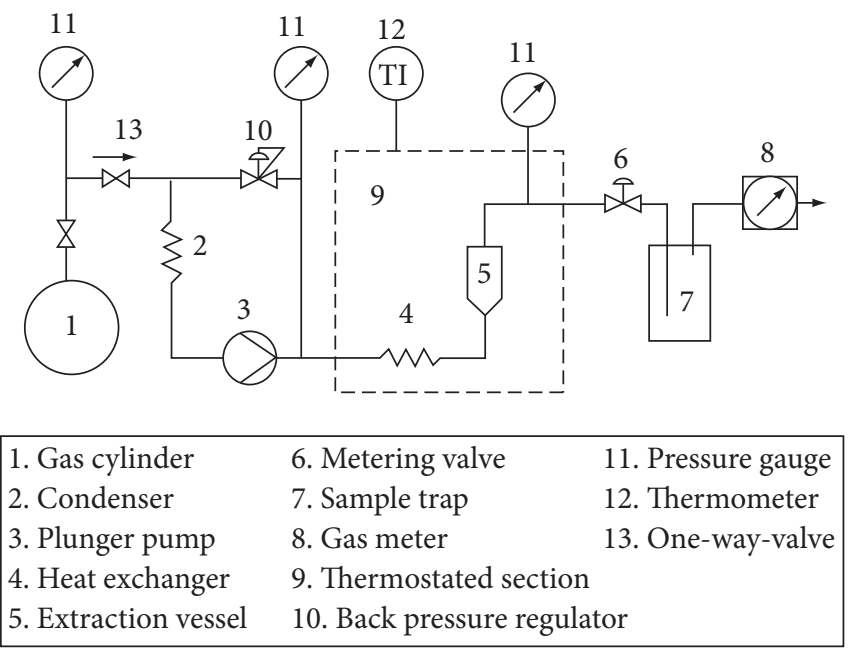

Figure 1. Flow chart of the SFE unit.

In the Soxhlet extraction, the solvents ethanol and hexane were used, of polarities 5.2 and 0.0 , respectively. The oleoresin was obtained as follows: $5 \mathrm{~g}$ of rosemary leaves (mesh $-20+32$ ) and $150 \mathrm{~mL}$ of solvent were placed inside a Soxhlet apparatus of $500 \mathrm{~mL}$ and kept under reflux for 4 hours. The solvent was removed using a rotary evaporator (Fisatom 802) with vacuum control (New Technique, Model NT 613, Piracicaba, SP, Brazil).

\subsection{Characterization of the rosemary extracts - GC-MS}

The chemical composition of the extracts (volatile oil and part of the oleoresin) was determined using gas chromatography (Varian ${ }^{\circ}$ CP-3800) coupled with mass spectrometry $\left(\right.$ Saturn $\left.^{\circ} 2000\right)$ detection and an electron ionization system, equipped with a capillary column CP-Sil 8 CB Low Bleed/MS (30 $\mathrm{m} \times 0.25 \mathrm{~mm}-0.25 \mu \mathrm{m}$ film). The carrier gas was He, with a gas flow of $1 \mathrm{~mL} / \mathrm{min}$. Oven temperature was kept at $60^{\circ} \mathrm{C}$ for 3 minutes and programmed to $220^{\circ} \mathrm{C}$ at a rate of $5{ }^{\circ} \mathrm{C} /$ minutes, then kept at $220^{\circ} \mathrm{C}$ for 5 minutes. Injector temperature was $250{ }^{\circ} \mathrm{C}$. Mass spectra were taken at $70 \mathrm{eV}$. The samples were diluted in an ethyl-acetate solution before analysis. The management software used was Saturn ${ }^{\circledR}$ GC/MS Workstation 5.51. The identification of the major compounds was based on i) a comparison of their mass spectra with those of data in the Standard Reference Data Series of the National Institute of Standards and Technology - NIST 98 MS Library; and ii) their retention index. Their quantification was carried out through the relative peak areas for individual constituents.

\subsection{Radical-scavenging activity (RSA) assay}

The capacity of the prepared extracts to scavenge the 'stable' free radical 1,1-diphenyl-2-picrylhydrazyl (DPPH) was monitored according to the method described by Mensor et al. (2001), with some slight modifications. To $1.0 \mathrm{~mL}$ of DPPH $(0.3 \mathrm{mM})$ in ethanol, $2.0 \mathrm{~mL}$ of varying concentrations of the test samples $\left(250,125,50,25,10\right.$ and $\left.5 \mu \mathrm{g} \cdot \mathrm{mL}^{-1}\right)$ were added. The reaction 
mixture was then allowed to stand at room temperature in a dark chamber for 30 minutes. The change in colour from deep violet to light yellow was measured at $517 \mathrm{~nm}$ in a spectrophotometer (Spectronic Unicam, model Genesys 10 vis, Rochester, NY, USA). The decrease in absorbance was then converted to percentage antioxidant activity using the Equation 1:

$\mathrm{AA} \%=100-\left\{\left[\left(\mathrm{Abs}_{\text {sample }}-\mathrm{Abs}_{\text {blank }}\right) \times 100\right] / \mathrm{Abs}_{\mathrm{DPPH}}\right\}$

Antioxidant activity of rosemary extracts was evaluated as $\mathrm{IC}_{50}$, equivalent to the amount of an extract that neutralizes $50 \%$ of the radical present. The linear regression of the data obtained from plots of test sample concentration against mean antioxidant activity (\%) was used to calculate the $\mathrm{IC}_{50}$ values.

\subsection{Total phenolic content}

For the total phenolic assay, Folin-Denis reagent was used according to the method cited by Jiao, Liu and Wang (2005). Quantification was carried out based on the standard curve of commercial tannic acid. A volume of $5 \mathrm{~mL}$ of Folin-Denis reagent was added to $5 \mathrm{~mL}$ of sample solution. After 3 minutes, $10 \mathrm{~mL}$ of saturated sodium carbonate and $80 \mathrm{~mL}$ of distilled water were added and mixed well. After exactly 30 minutes, the absorbance at $760 \mathrm{~nm}$ was measured. The result was calculated according to the standard and expressed as grams of tannic acid equivalent (TAE) per $100 \mathrm{~g}$ of extract.

\subsection{Antimicrobial activity (MIC)}

The antibacterial activity of the essential oils was investigated by employing a microdilution method. The assay was carried out with four bacterial species: Escherichia coli ATCC 25922 (American Type Culture Collection), Pseudomonas aeruginosa ATCC 27853, Staphylococcus aureus ATCC 25923 and Bacillus cereus ATCC 11778, and one fungal species, Candida albicans ATCC 14053. Mueller-Hinton agar and broth (Difco Laboratories, Detroit, USA) were used for bacterial growth and nutrient agar for fungal growth. The inoculum was an overnight culture of each bacterial species in Mueller-Hinton broth diluted in the same media to a final concentration of approx. $10^{8}$ CFU.mL ${ }^{-1}$. Essential oils were dissolved in dimethyl sulfoxide (DMSO) (10\% of the final volume) and diluted with Mueller-Hinton broth (Difco Laboratories) to a concentration of $2 \mathrm{mg} \cdot \mathrm{mL}^{-1}$. Further 1:2 serial dilutions were performed by addition of Mueller-Hinton broth to reach a final concentration within a range of 2 to $0.0156 \mathrm{mg} \cdot \mathrm{mL}^{-1}$. One hundred microlitres of each dilution were placed into 96-well plates, and a sterility control was also carried out (growth control contained Mueller-Hinton broth plus DMSO, without antimicrobial substances). Each test and growth control well was inoculated with $5 \mu \mathrm{L}$ of a bacterial suspension $\left(10^{8} \mathrm{CFU} \cdot \mathrm{mL}^{-1}\right.$ or $\left.10^{5} \mathrm{CFU} \cdot \mathrm{well}^{-1}\right)$. All experiments were performed in triplicate and the microdilution trays were incubated at $36^{\circ} \mathrm{C}$ for 18 hours. Bacterial growth was detected first by optical density (ELISA reader, CLX800-BioTek Instruments) and then by addition of $20 \mu \mathrm{L}$ of an alcoholic solution (0.5 mg. $\left.\mathrm{mL}^{-1}\right)$ of 2-(4-iodophenyl)-3-(4-nitrophenyl)-5phenyltetrazolium chloride (INT) (Sigma). The trays were again incubated at $36^{\circ} \mathrm{C}$ for 30 minutes, and, in the wells where bacterial growth occurred, the INT changed from yellow to purple.
MIC values were defined as the lowest concentration of each oil which completely inhibited microbial growth. The results were expressed in milligrams per millilitre.

\section{Results and discussion}

The mean moisture content of the rosemary leaves was $9.6 \%$ (dry basis: d.b.). The mean particle diameter was $11.42 \times 10^{-4} \mathrm{~m}$, and the true density of the particles was $1330 \mathrm{~kg} . \mathrm{m}^{-3}$.

\subsection{Global yield and chemical composition}

Table 1 shows the global yields for the supercritical extract and Soxhlet extract of the rosemary leaves. The global yield was found to increase with pressure. For high pressures (200 and 300 bar), there was an increase in the extraction yield with temperature and the opposite behaviour was observed for low pressures (100 bar). This behaviour was also reported by Carvalho-Junior et al. (2003), who, for a supercritical rosemary extract, reported a cross-over point at 177 bar, where for lower pressures the global yield decreased with temperature, and for higher pressures the global yield increased with temperature.

The highest global yield for SFE (3.52\% d.b.) was obtained at 300 bar $/ 50^{\circ} \mathrm{C}$ and the lowest $\left(1.50 \%\right.$ d.b.) at $100 \mathrm{bar} / 50{ }^{\circ} \mathrm{C}$. These yields were lower than those obtained using ethanol extraction (30.25\% d.b.) and hexane extraction ( $8.76 \%$ d.b.).

Different kinds of rosemary leaf extracts were tested by GC-MS. Their percent composition is shown in Table 2. The most abundant component in all samples was isocarnosol. Carnosol is known as a major antioxidant in rosemary (WEI; $\mathrm{HO}, 2006)$. The extracts also contained $\alpha$-pinene, bornyl acetate, camphor and carvacrol, which are responsible for the antimicrobial activity in rosemary (BURT, 2004; DAFERERA; ZIOGAS; POLISSIOU, 2000; 2003; PINTORE et al., 2002). The composition of the rosemary extracts was qualitatively similar to those obtained by other authors (PANIZZI et al., 1993; KABOUCHE et al., 2005; QUISPE-CONDORI et al., 2005; SACCHETTI et al., 2005; GACHKAR et al., 2007), but with a different quantitative composition. Differences in rosemary oil composition have already been reported (SACCHETTI et al., 2005). These differences in the chemical compositions of oils

Table 1. Comparison of yields obtained for Soxhlet and supercritical $\mathrm{CO}_{2}$ extraction of Rosmarinus officinalis.

\begin{tabular}{clc}
\hline Assay number & \multicolumn{1}{c}{ Extraction method } & Yield (\% dry basis) \\
\hline 1 & Soxhlet extraction-hexane & 8.76 \\
2 & Soxhlet extraction-ethanol & 30.25 \\
3 & SFE: $30^{\circ} \mathrm{C} / 100$ bar & 2.41 \\
4 & SFE: $40^{\circ} \mathrm{C} / 100$ bar & 2.27 \\
5 & SFE: $50^{\circ} \mathrm{C} / 100$ bar & 1.50 \\
6 & SFE: $30^{\circ} \mathrm{C} / 200$ bar & 2.56 \\
7 & SFE: $40^{\circ} \mathrm{C} / 200$ bar & 2.66 \\
8 & SFE: $50^{\circ} \mathrm{C} / 200$ bar & 3.32 \\
9 & SFE: $30^{\circ} \mathrm{C} / 300$ bar & 3.10 \\
10 & SFE: $40^{\circ} \mathrm{C} / 300$ bar & 3.18 \\
11 & SFE: $50^{\circ} \mathrm{C} / 300$ bar & 3.52 \\
\hline
\end{tabular}


Table 2. Percentage composition of rosemary extracts as a function of the extraction method, operating pressure and temperature.

\begin{tabular}{|c|c|c|c|c|c|c|c|c|c|c|c|}
\hline \multicolumn{12}{|c|}{ Assay number } \\
\hline & 1 & 2 & 3 & 4 & 5 & 6 & 7 & 8 & 9 & 10 & 11 \\
\hline$\alpha$-pinene & 1.68 & - & 0.57 & 0.53 & 1.61 & 1.27 & - & 0.61 & - & 0.81 & 0.37 \\
\hline$\alpha$-phellandrene & - & - & - & - & - & 0.58 & - & 0.54 & - & 0.44 & 0.43 \\
\hline Terpinolene & - & - & - & - & - & 0.54 & - & 0.50 & - & 0.39 & 0.32 \\
\hline Limonene & 2.70 & - & 0.55 & 0.58 & 1.44 & 1.45 & 0.84 & 1.01 & 0.87 & 0.97 & 0.60 \\
\hline$\beta$-phellandrene & - & - & - & - & 1.41 & 0.62 & - & 0.66 & - & 0.59 & 0.51 \\
\hline Camphor & 6.75 & 6.60 & 1.82 & 1.91 & 4.71 & 5.34 & 7.72 & 5.51 & 2.84 & 4.22 & 4.46 \\
\hline Borneol & 1.21 & 1.19 & 0.54 & 0.78 & 2.13 & 1.63 & 2.97 & 1.93 & - & 1.87 & 1.51 \\
\hline Terpinen-4-ol & - & - & - & - & - & 0.65 & 1.13 & 0.86 & - & 0.66 & 0.60 \\
\hline Terpineol & 0.92 & - & 0.67 & 0.92 & 2.26 & 1.62 & 2.70 & 1.97 & 0.93 & 1.55 & 1.30 \\
\hline Verbenone & 5.32 & 5.21 & 2.42 & 3.09 & 8.98 & 7.17 & 13.02 & 9.33 & 4.68 & 6.69 & 6.54 \\
\hline Carvacrol & - & - & - & - & - & - & - & - & - & 0.30 & 0.22 \\
\hline Bornyl acetate & 1.82 & 1.45 & 0.70 & 0.84 & 2.02 & 1.90 & 3.53 & 2.05 & 0.91 & 1.93 & 1.79 \\
\hline Caryophyllene & 2.37 & 2.48 & 2.11 & - & 6.97 & - & 8.95 & 6.33 & 2.66 & 5.43 & 4.39 \\
\hline$\alpha$-humulene & - & - & - & 0.79 & 1.74 & 1.21 & 1.77 & 1.37 & - & 1.18 & 0.95 \\
\hline Methyl jasmonate & - & - & - & 0.96 & 2.86 & 0.89 & 0.96 & 1.14 & - & 0.80 & 0.52 \\
\hline$\alpha$-bisabolol & - & - & - & 0.50 & 1.58 & - & - & 0.52 & - & 0.39 & 0.29 \\
\hline Benzenesulfonamide, $n$-butyl ${ }^{-}$ & - & - & 2.69 & 1.67 & 2.21 & 0.62 & 1.72 & 0.45 & 2.02 & 0.48 & 0.26 \\
\hline Phytol & - & - & 0.90 & 1.40 & 3.65 & 1.13 & - & 1.02 & - & 1.12 & 0.69 \\
\hline Sclareol & - & - & 0.55 & 1.02 & 2.65 & 1.08 & 1.10 & 1.50 & - & 0.68 & 0.78 \\
\hline Ferruginol & 0.83 & 1.63 & 2.21 & 4.21 & 10.22 & 3.59 & 4.14 & 6.14 & 1.93 & 2.44 & 2.42 \\
\hline Hinokione & 0.76 & 0.97 & 1.16 & 0.85 & 5.36 & 2.09 & - & 2.01 & 2.21 & 1.12 & 1.04 \\
\hline Isocarnosol & 41.65 & 69.39 & 65.55 & 40.44 & 19.77 & 44.12 & 37.19 & 31.73 & 68.04 & 44.06 & 42.37 \\
\hline Dihydronormorphinone & 14.31 & 8.62 & 5.33 & 14.34 & - & 4.18 & 5.28 & 3.36 & 6.67 & 3.60 & 4.68 \\
\hline Not identified & 19.68 & 2.46 & 12.23 & 25.17 & 18.43 & 18.32 & 6.98 & 19.46 & 6.24 & 18.28 & 22.96 \\
\hline
\end{tabular}

could be attributed to climatic effects on the plants (GACHKAR et al., 2007). Besides, the following factors should be considered when observing differences between studies: 1) genotypic and environmental differences within species; 2 ) sample extraction time; and 3) extraction technique used to obtain the rosemary oil or extract.

\subsection{Free radical-scavenging activity: DPPH test}

The DPPH radical-scavenging activities are presented in terms of the $\mathrm{IC}_{50}$ values and are shown in Table 3. The $\mathrm{IC}_{50}$, meaning the concentration of antioxidant, or extract, needed to decrease (by $50 \%$ ) the initial substrate concentration, is a parameter widely used to measure antiradical efficiency (KANNER et al., 1994; VINSON et al., 1995; XU; CHEN; HU, 2005). The lower the $\mathrm{IC}_{50}$ indicates the higher the antioxidant power.

All extracts exhibited antioxidant activity, and the lowest $\mathrm{IC}_{50}$ value for SFE $\left(12.85 \mu \mathrm{g} \cdot \mathrm{mL}^{-1}\right)$ was obtained in two operation conditions, at $200 \mathrm{bar} / 40^{\circ} \mathrm{C}$ and at $300 \mathrm{bar} / 40^{\circ} \mathrm{C}$. The highest $\left(27.34 \mu \mathrm{g} . \mathrm{mL}^{-1}\right)$ was obtained at $100 \mathrm{bar} / 30^{\circ} \mathrm{C}$. These values were higher than that for the hexane-extract $\left(9.23 \mu \mathrm{g} \cdot \mathrm{mL}^{-1}\right)$. The value of $\mathrm{IC}_{50}=15.73 \mu \mathrm{g} \cdot \mathrm{mL}^{-1}$ was determined for the ethanolextract. Mata et al. (2007) obtained a value of $36.0 \mu \mathrm{g} \cdot \mathrm{mL}^{-1}$. A value of $\mathrm{IC}_{50}=86 \mu \mathrm{g} \cdot \mathrm{mL}^{-1}$ for rosemary essential oil was found by Almela et al. (2006) in their study. It is known that antioxidant activity depends, first, on genetic and growth conditions, such
Table 3. Radical-scavenging activity of rosemary leaf extracts expressed by $\mathrm{IC}_{50}$.

\begin{tabular}{clc}
\hline Assay number & \multicolumn{1}{c}{ Extraction method } & $\mathrm{IC}_{50}\left(\mu \mathrm{g} \cdot \mathrm{mL}^{-1}\right)$ \\
\hline 1 & Soxhlet extraction-hexane & 9.23 \\
2 & Soxhlet extraction-ethanol & 15.73 \\
3 & SFE: $30^{\circ} \mathrm{C} / 100$ bar & 27.34 \\
4 & SFE: $40^{\circ} \mathrm{C} / 100$ bar & 14.30 \\
5 & SFE: $50^{\circ} \mathrm{C} / 100$ bar & 26.21 \\
6 & SFE: $30^{\circ} \mathrm{C} / 200$ bar & 24.75 \\
7 & SFE: $40^{\circ} \mathrm{C} / 200$ bar & 12.85 \\
8 & SFE: $50^{\circ} \mathrm{C} / 200$ bar & 22.89 \\
9 & SFE: $30^{\circ} \mathrm{C} / 300$ bar & 23.10 \\
10 & SFE: $40^{\circ} \mathrm{C} / 300$ bar & 12.85 \\
11 & SFE: $50^{\circ} \mathrm{C} / 300$ bar & 25.84 \\
\hline
\end{tabular}

as the quality of the original plant, its geographical origin and the climatic conditions, harvesting date, and storage and processing, and, second, on the extraction process and its selected parameters (CAVERO et al., 2005).

The SFE condition of $300 \mathrm{bar} / 40^{\circ} \mathrm{C}$ was chosen to evaluate the influence of extraction time on antioxidant activity. These results are shown in Table 4.

The radical-scavenging (antioxidant) activity improves with increasing extraction time. The $\mathrm{IC}_{50}$ value of $4.68 \mu \mathrm{g} \cdot \mathrm{mL}^{-1}$ was reached with an extraction time of 120 to 150 minutes. 


\subsection{Total phenolic content}

Total phenolic content was estimated by the Folin-Denis colorimetric method, based on the procedure cited by Jiao, Liu and Wang (2005), using tannic acid as standard phenolic compound. A linear calibration curve of tannic acid, with an $\mathrm{r}^{2}$ value of 0.9992 , was constructed. The total phenolic content was expressed as tannic acid equivalents (TAE) in milligrams per gram of extract. The concentration of phenolics in the extracts (mgTAE/g extract) was dependent on the solvent and on the SFE experimental conditions, as shown in Table 5.

The amount of phenolic compounds in the ethanol extract (14.20 $\mathrm{g}$ of TAE/100 $\mathrm{g}$ of extract) was the highest. For the SFE, the total phenolic content ranged from 7.45 to $13.51 \mathrm{~g}$ of TAE $/ 100 \mathrm{~g}$ of extract, with an overall mean of $10.06 \mathrm{~g}$ of TAE/100 g of extract. The total phenolic content was independent of pressure and temperature. All of the values obtained for the rosemary leaf extracts were higher than those presented by Goli, Barzegar and Sahari (2005) for pistachio hull extracts.

The relationships between total phenolic content and antioxidant properties of many plants have been investigated in previous studies (ZHENG; WANG, 2001; VELIOGLU et al., 1998; DORMAN et al., 2004; MOREIRA et al., 2005). Some studies obtained good positive linear correlations; others ob-

Table 4. Radical-scavenging activity (expressed by $\mathrm{IC}_{50}$ ) as a function of extraction time for rosemary leaves extracted by SFE at $300 \mathrm{bar} / 40^{\circ} \mathrm{C}$.

\begin{tabular}{cc}
\hline Time (minutes) & $\mathrm{IC}_{50}\left(\mu \mathrm{g} \cdot \mathrm{mL}^{-1}\right)$ \\
\hline $0-10$ & 41.76 \\
$10-20$ & 29.54 \\
$20-30$ & 26.48 \\
$30-40$ & 25.46 \\
$40-50$ & 24.21 \\
$50-60$ & 21.37 \\
$60-80$ & 18.53 \\
$80-100$ & 13.71 \\
$100-120$ & 8.12 \\
$120-150$ & 4.68 \\
\hline
\end{tabular}

Table 5. Total phenolic content of rosemary leaf extracts.

\begin{tabular}{clc}
\hline Assay number & \multicolumn{1}{c}{ Extraction method } & $\begin{array}{c}\text { Phenolic content } \\
\left(\mathrm{g}_{\text {TAE }} / 100 \mathrm{~g}_{\text {extract }}\right)\end{array}$ \\
\hline 1 & Soxhlet extraction-hexane & 11.13 \\
2 & Soxhlet extraction-ethanol & 14.20 \\
3 & SFE: $30^{\circ} \mathrm{C} / 100$ bar & 11.51 \\
4 & SFE: $40^{\circ} \mathrm{C} / 100$ bar & 8.42 \\
5 & SFE: $50^{\circ} \mathrm{C} / 100$ bar & 8.49 \\
6 & SFE: $30^{\circ} \mathrm{C} / 200$ bar & 7.45 \\
7 & SFE: $40^{\circ} \mathrm{C} / 200$ bar & 8.07 \\
8 & SFE: $50^{\circ} \mathrm{C} / 200$ bar & 10.74 \\
9 & SFE: $30^{\circ} \mathrm{C} / 300$ bar & 13.51 \\
10 & SFE: $40^{\circ} \mathrm{C} / 300$ bar & 9.11 \\
11 & SFE: $50^{\circ} \mathrm{C} / 300$ bar & 13.27 \\
\hline
\end{tabular}

${ }^{a g}$ tannic acid equivalents per $100 \mathrm{~g}$ rosemary leaf extract. tained poor linear correlations or even could not explain the relationship between total antioxidant activity and phenolic content, as presented by Mata et al. (2007), and as occurred in our studies.

\subsection{Antimicrobial activity (MIC)}

Antimicrobial activity was studied using the SFE extracts with the highest antioxidant potential. Thus, the antibacterial and antifungal activities of the SFE extract obtained at $300 \mathrm{bar}$ and $40{ }^{\circ} \mathrm{C}$ were investigated. MIC values were defined as the lowest concentration of the oil which completely inhibited microbial growth. The results were expressed in milligrams per millilitre. The results for the MIC are shown in Table 6. Three samples were obtained by SFE, at different extraction times, and each sample was analysed.

The results indicated that the rosemary extracts showed antibacterial activity, according to Weckesser et al. (2007), mainly against the Gram-positive bacteria (S. aureus and B. cereus). The extracts also exhibited an effect against the Gram-negative bacteria ( $E$. coli and P. aeruginosa). However, this effect was less efficient than that presented against the Gram-positive bacteria, since a higher MIC value was obtained with the Gram-negative bacteria. A similar behaviour was reported by Panizzi et al. (1993). For the Gram-negative bacteria, the extracts showed the same antibacterial effect, regardless of the extraction time. For the Gram-positive bacteria, the extracts became more efficient with increasing extraction time for S. aureus, and the contrary was observed for B. cereus. With regard to the antifungal activity, the extract obtained in the first 60 minutes did not present sufficient antifungal activity to inhibit the growth of $C$. albicans. The extract obtained with a longer extraction period showed antifungal activity, which improved with increasing extraction time. A good to moderate antimicrobial activity of rosemary essential oil has been reported by several authors (GACHKAR et al., 2007; CELIKTAS et al., 2007).

\section{Conclusions}

The antioxidant, antibacterial and antifungal activities of the SFE extracts were confirmed. With regard to antibacterial activity, the oils are more active against Gram-positive, than Gram-negative, bacteria, as evidenced by the lower MIC values for the former. Rosemary extracts obtained by supercritical $\mathrm{CO}_{2}$ extraction were shown to be promising with regard to their incorporation into various foods, cosmetics and pharmaceutical

Table 6. Antimicrobial activity (expressed by MIC) as a function of extraction time for rosemary leaf extract obtained by SFE at 300 bar $/ 40^{\circ} \mathrm{C}$.

\begin{tabular}{|c|c|c|c|c|c|}
\hline \multirow{3}{*}{$\begin{array}{c}\text { Time } \\
\text { (minutes) }\end{array}$} & \multicolumn{5}{|c|}{ MIC (mg.mL $\left.{ }^{-1}\right)$} \\
\hline & \multicolumn{4}{|c|}{ Antibacterial activity } & \multirow{2}{*}{$\begin{array}{l}\text { Antifungal } \\
\text { activity } \\
\text { C. albicans }\end{array}$} \\
\hline & E. coli & P. aeruginosa & S. aureus & B. cereus & \\
\hline $0-60$ & 1.0 & 1.0 & 0.5 & 0.062 & $>2.0$ \\
\hline $60-120$ & 1.0 & 1.0 & 0.25 & 0.125 & 1.0 \\
\hline $120-240$ & 1.0 & 1.0 & 0.25 & 0.125 & 0.5 \\
\hline
\end{tabular}


products for which a natural aroma, colour, and antioxidant/ antimicrobial additive is desired. These properties are also needed by the food industry in order to find possible alternatives to synthetic preservatives. Further studies are necessary to investigate the incorporation of extracts into appropriate food formulations, and evaluate flavour, chemical changes and antioxidant and antimicrobial activities in the whole food system.

\section{Acknowledgements}

The authors thank CNPq for the research grants and Duas Rodas Industrial Ltda. for their support.

\section{References}

A.O.A.C - Association of Official Agricultural Chemists. Official methods of analysis. 11 ed. Washington. D.C. 1141, 1990.

ALMELA, L. et al. Liquid chromatographic-mass spectrometric analysis of phenolics and free radical scavenging activity of rosemary extract from different raw material. Journal of Chromatography A, Murcia, v. 1120, n. 1-2, p. 221-229, 2006.

BURT, S. Essential oils: their antibacterial properties and potential applications in foods - a review. International Journal of Food Microbiology, Utrecht, v. 94, n. 3, p. 223-253, 2004.

CARVALHO-JUNIOR, R. S. et al. Determination of the global yield isotherms for the system rosemary (Rosmarinus officinalis) + $\mathrm{CO} 2$. In: INTERNATIONAL SYMPOSIUM ON SUPERCRITICAL FLUIDS, 6, Versailles, 2003. Proceedings of the $6^{\text {th }}$ International Symposium on SUPERCRITICAL FLUIDS, Versailles: ISASF, 2003. $129-137 \mathrm{p}$.

CAVERO, S. et al. In vitro antioxidant analysis of supercritical fluid extracts from rosemary (Rosmarinus officinalis L.). European Food Research \& Technology, Madrid, v. 221, n. 3-4, p. 478-486, 2005.

CELIKTAS, O. Y. et al. Antimicrobial activities of methanol extracts and essential oils of Rosmarinus officinalis, depending on location and seasonal variations. Food Chemistry, Bornova-Izmir/Eskisehir, v. 100, n. 2, p. 553-559, 2007.

DAFERERA, D. J.; ZIOGAS, B. N.; POLISSIOU, M. G. GC-MS analysis of essential oils from some Greek aromatic plants and their fungitoxicity on Penicillium digitatum. Journal of Agricultural and Food Chemistry, Athens, v. 48, n. 6, p. 2576-2581, 2000.

The effectiveness of plant essential oils in the growth of Botrytis cinerea, Fusarium sp. and Clavibacter michiganensis subsp. michiganensis. Crop Protection, Athens, v. 22, n. 1, p. 39-44, 2003.

DORMAN, H. J. D. et al. Antioxidant properties of aqueous extracts from selected Lamiaceae species grown in Turkey. Journal of Agricultural and Food Chemistry, Helsinki, v. 52, n. 4, p. 762-770, 2004.

FERNÁNDEZ-LÓPEZ, J. et al. Antioxidant and antibacterial activities of natural extracts: application in beef meatballs. Meat Science, Alicante/Newton Abbot, v. 69, n. 3, p. 371-380, 2005.

FRANKEL, E. N. et al. Antioxidant activity of a rosemary extract and its constituents, carnosic acid, carnosol, and rosmarinic acid, in bulk oil and oil-in-water emulsion. Journal of Agricultural and Food Chemistry, Davis/Lausanne, v. 44, n. 1, p. 131-135, 1996.

GACHKAR, L. et al. Chemical and biological characteristics of Cuminum cyminum and Rosmarinus officinalis essential oils. Food Chemistry, Tehran, v. 102, n. 3, p. 898-904, 2007.
GOLI, A. H.; BARZEGAR, M.; SAHARI, M. A. Antioxidant activity and total phenolic compounds of pistachio (Pistachia vera) hull extracts. Food Chemistry, Tehran, v. 92, n. 3, p. 521-525, 2005.

JIAO, Z.; LIU, J.; WANG, S. Antioxidant Activities of Blackberry Pigment Extract. Food Technology and Biotechnology, Zhengzhou, v. 43, n. 1, p. 97-102, 2005.

KABOUCHE, Z. et al. Comparative antibacterial activity of five Lamiaceae essential oils from Algeria. The International Journal of Aromatherapy, Constantine, v. 15, n. 3, p. 129-133, 2005.

KANNER, J. et al. Natural antioxidants in grapes and wines. Journal of Agricultural and Food Chemistry, Bet Dagan/Davis, v. 42, n. 1, p. 64-69, 1994.

LEAL, P. F. et al. Functional Properties of Spice Extracts Obtained via Supercritical Fluid Extraction. Journal of Agricultural and Food Chemistry, Campinas, v. 51, n. 9, p. 2520-2525, 2003.

MATA, A. T. et al. Antioxidant and antiacetylcholinesterase activities of five plants used as Portuguese food spices. Food Chemistry, Lisbon, v. 103, n. 3, p. 778-786, 2007.

MENSOR, L. L. et al. Screening of Brazilian plant extracts for antioxidant activity by the use of DPPH free radical method. Phytotherapy Research, England, v. 15, n. 2, p. 127-130, 2001.

MOREIRA, M. R. et al. Inhibitory parameters of essential oils to reduce a foodborne pathogen. LWT - Food Science and Technology, Mar del Plata, v. 38, n. 5, p. 565-570, 2005.

OLUWATUYI, M.; KAATZ, G. W.; GIBBONS, S. Antibacterial and resistance modifying activity of Rosmarinus officinalis. Phytochemistry, London/Detroit, v. 65, n. 24, p. 3249-3254, 2004.

OUATTARA, B. et al. Antibacterial activity of selected fatty acids and essential oils against six meat spoilage organisms. International Journal of Food Microbiology, Québec/Mannitoba, v. 37, n. 2-3, p. 155-162, 1997.

PANIZZI, L. et al. Composition and antimicrobial properties of essential oils of four Mediterranean Lamiaceae. Journal of Ethnopharmacology, Livorno/Pisa, v. 39, n. 3, p. 167-170,1993.

PENG, Y. et al. Determination of active components in rosemary by capillary electrophoresis with electrochemical detection. Journal of Pharmaceutical and Biomedical Analysis, Fujian/Shanghai, v. 39, n. 3-4, p. 431-437, 2005.

PINTORE, G. et al. Chemical composition and antimicrobial activity of Rosmarinus officinalis L. oils from Sardinia and Corsica. Flavour and Fragrance Journal, Sassari/Ajaccio, v. 17, n. 1, p. 15-19, 2002.

PROESTOS, C.; SERELI, D.; KOMAITIS, M. Determination of phenolic compounds in aromatic plants by RP-HPLC and GC-MS. Food Chemistry, Athens, v. 95, n. 1, p. 44-52, 2006.

QUISPE-CONDORI, S. et al. Global yield isotherms and kinetic of artemisinin extraction from Artemisia annua L leaves using supercritical carbon dioxide. Journal of Supercritical Fluids, Sao Paulo/Hamburg, v. 36, n. 1, p. 40-48, 2005.

REZZOUG, S. A.; BOUTEKEDJIRET, C.; ALLAF, K. Optimization of operating conditions of rosemary essential oil extraction by a fast controlled pressure drop process using response surface methodology. Journal of Food Engineering, La Rochelle/Algiers, v. 71, n. 1, p. 9-17, 2005.

RICE-EVANS, C. A.; MILLER, N. J.; PAGANGA, G. Antioxidant properties of phenolic compounds. Trends in Plant Science, London, v. 2, n. 4, p. 152-159, 1997.

SACCHETTI, G. et al. Comparative evaluation of 11 essential oils of different origin as functional. Food Chemistry, Ferrara/Macas/ Parma, v. 91, n. 4, p. 621-632, 2005. 
TAWAHA, K. et al. Antioxidant activity and total phenolic content of selected Jordanian plant species. Food Chemistry, Amman/Irbid, v. 104, n. 4, p. 1372-1378, 2007.

VÁGI, E. et al. Essential oil composition and antimicrobial activity of Origanum majorana L. extracts obtained with ethyl alcohol and supercritical carbon dioxide. Food Research International, Budapest, v. 38, n. 1, p. 51-57, 2005.

VALERO, M.; SALMERÓN, M. C. Antibacterial activity of 11 essential oils against Bacillus cereus in tyndallized carrot broth. International Journal of Food Microbiology, Alicante, v. 85, n. 1-2, p. 73-81, 2003.

VELIOGLU, Y. S. et al. Antioxidant activity and total phenolics in selectec fruits, vegetables, and grain products. Journal of Agricultural and Food Chemistry, British Columbia, v. 46, n. 10, p. 4113-4117, 1998.

VINSON, J. A. et al. Plant polyphenols exhibit lipoprotein-bound antioxidant activity using an in vitro oxidation model heart disease. Journal of Agricultural and Food Chemistry, Scranton, v. 43, n. 11, p. 2798-2799, 1995.
XU, J.; CHEN, S.; HU, Q. Antioxidant activity of brown pigment and extracts from black sesame seed (Sesamum indicum L.). Food chemistry, Nanjing/Changshu, v. 91, n. 1, p. 79-83, 2005.

WECKESSER, S. et al. Screening of plant extracts for antimicrobial activity against bacteria and yeasts with dermatological relevance. Phytomedicine, Freiburg, v. 14, n. 7-8, p. 508-516, 2007.

WEI, G. J.; HO, C. T. A stable quinone identified in the reaction of carnosol, a major antioxidant in rosemary, with 2,2-diphenyl-1picrylhydrazyl radical. Food Chemistry, New Brunswick, v. 96, n. 3, p. 471-476, 2006.

ZETZL, C.; BRUNNER, G.; MEIRELES, M. A. A. Standardized low cost SFE units for university education and comparative research. In: PERRUT, M.; BRUNNER, G.; KIKIC, I. (Eds.). Proceedings of the $6^{\text {th }}$ International Symposium on Supercritical Fluids, 2003.

ZHENG, W.; WANG, S. Y. Antioxidant activity and phenolic compounds in selected herbs. Journal of Agricultural and Food Chemistry, Beltsville, v. 49, n. 11, p. 5165-5170, 2001. 